Article

\title{
Selective Hydrogenation of 3-Nitrostyrene over a Co-promoted Pt Catalyst Supported on P-containing Activated Charcoal
}

\author{
Qifan Wu ${ }^{1,2,3}$, Chao Zhang ${ }^{1,3, * \mathbb{C}}$, Weiwei Lin ${ }^{1,3}$, Haiyang Cheng ${ }^{1,3}$, Masahiko Arai ${ }^{1,3}$ and \\ Fengyu Zhao 1,2,3,* \\ 1 State Key Laboratory of Electroanalytical Chemistry, Changchun Institute of Applied Chemistry, Chinese \\ Academy of Sciences, Changchun 130022, China; qifanwu@ciac.ac.cn (Q.W.); linwei@ciac.ac.cn (W.L.); \\ hycyl@ciac.ac.cn (H.C.); marai@eng.hokudai.ac.jp (M.A.) \\ 2 School of Applied Chemistry and Engineering, University of Science and Technology of China, \\ Hefei 230026, China \\ 3 Laboratory of Green Chemistry and Process, Changchun Institute of Applied Chemistry, Chinese Academy \\ of Sciences, Changchun 130022, China \\ * Correspondence: czhang@ciac.ac.cn (C.Z.); zhaofy@ciac.ac.cn (F.Z.); Tel.: +86-431-85262410 (F.Z.)
}

Received: 12 April 2019; Accepted: 28 April 2019; Published: 8 May 2019

\begin{abstract}
A series of Co-modified Pt catalysts supported on P-containing activated charcoal were studied for the selective hydrogenation of 3-nitrostyrene (NS) to 3-aminostyrene (AS). The addition of Co decreased the rate of hydrogenation but enhanced the selectivity to AS, being $92 \%$ at nearly $100 \%$ conversion over an optimized catalyst. The high AS selectivity should result from the configuration of NS adsorption on the catalyst, which occurs preferentially with its $-\mathrm{NO}_{2}$ group on the $\mathrm{Pt}-\mathrm{PO}_{\mathrm{x}}$ interface layer over the surface of supported $\mathrm{Pt}$ particles. The formation of such a $\mathrm{Pt}-\mathrm{PO}$ area is promoted by the Co additive.
\end{abstract}

Keywords: selective hydrogenation; 3-nitrostyrene; bimetallic catalysts

\section{Introduction}

Carbon materials have been utilized in a wide variety of applications owing to high elemental abundance and diverse bonding capability of carbon atoms. The doping of carbon materials with heteroatoms (B, N, O, P, and S) broadens the fields of the application of carbon materials. Heteroatom-doped carbon materials have attracted much attention in the field of heterogeneous catalysis owing to their tunable surface structures and electronic properties [1-12]. The influence of $\mathrm{N}$-doping to carbon materials on their catalytic performance has been extensively studied [13-15]. Synergistic effects of nitrogen atoms in the carbon architecture combined with metal nanoparticles can find application in a wide range of catalytic reactions [16]. In addition, phosphorus $(\mathrm{P})$ has the same number of valence electrons as nitrogen, but bigger atomic radius and better electron-donating ability than nitrogen, which could change local charge density through its lone pair electrons in the $3 p$ orbital. Such characters are effective to improve the electronic density of nearby carbon atoms and produce defect sites in P-doped carbon materials [17-20]. Consequently, such surface modifications would lead to a change in the performance of supported catalysts thereon [21-26]. For instance, P-doped carbon materials could promote the dispersion of supported Pt nanoparticles, which is beneficial for improving catalytic activity [26-29]. Moreover, the significant orbital hybridization between the transition metal $s d$ hybridized orbital and P sp hybridized orbital, changes the electronic structure of the metal, which has positive impacts on the catalytic activity of the metals [7]. The interactions between 
P-containing species and the metal active sites could also influence the adsorption configurations of reactants adsorbed on the catalysts [7,17].

Hydrogenation reactions are practically important chemical processes [10,30-35], and, for example, those of aromatic nitro compounds to anilines are widely used for the manufacture of pharmaceuticals, pesticides, fine chemicals, and pigments [36-42]. Although the selective hydrogenation of nitro groups have been widely investigated so far, efforts still need to design more selective catalysts.

Supported PtCo catalysts have been studied in catalytic hydrogenation due to their unique electronic, geometric, and structural properties, and these bimetallic catalysts show excellent catalytic performances in the selective hydrogenation of $\mathrm{C}=\mathrm{O}, \mathrm{C}=\mathrm{C}, \mathrm{N}=\mathrm{O}$, and others [43-48]. For cinnamaldehyde hydrogenation, for instance, $91 \%$ selectivity to cinnamyl alcohol (COL) was obtained on $\mathrm{Pt}_{3} \mathrm{Co} / \mathrm{Co}(\mathrm{OH})_{2}$ catalystsowning to the modified electron density of $\mathrm{Pt}$ [49]. A selectivity to COL $(>90 \%)$ was achieved over Pt-Co/MWCNTs (multi-walled carbon nanotubes), which was attributed to the synergistic effect between Pt-Co and MWCNTs [43]. Thus, Co can be an interesting additive and modifier to change the catalytic performances of supported Pt catalysts. Recently the authors have found that the selectivity of carbon-supported Pt catalyst in liquid phase hydrogenation of 3-nitrostyrene (NS) can be switched by the modification of the Pt by phosphorous species, from ethylnitrobenzene (ENB)—selective to aminostyrene (AS)—selective. That is, the nitro group of NS is selectively hydrogenated to AS with Pt catalyst supported on P-containing activated charcoal (PAC) compared with the vinyl group [50]. In a Pt/PAC catalyst, $\mathrm{Pt}-\mathrm{PO}_{\mathrm{x}}$ interfacial layer is formed on the surface of Pt particles and promotes the adsorption of NS with its nitro group. In the present work, after considering above-mentioned interesting impacts of Co on Pt catalysts and our previous results with $\mathrm{Pt} / \mathrm{PAC}$, the influence of $\mathrm{Co}$ additive to $\mathrm{Pt} / \mathrm{PAC}$ on the product selectivity in the same hydrogenation has been studied. It is interesting to note that the AS selectivity is further enhanced by the addition of a Co modifier to Pt/PAC. Synergistic roles of Co additive and surface P species in changing the product selectivity have been examined and discussed on the basis of reaction and catalyst characterization results (transmission electron microscopy (TEM), X-ray powder diffraction (XRD), temperature programmed reduction (TPR), X-ray photoelectron spectroscopy (XPS), and in-situ diffuse reflectance infrared Fourier transform spectroscopy (DRIFTS)). In addition, the influence of catalyst preparation methods (successive impregnation, co-impregnation) has also been studied.

\section{Results and Discussion}

The preparation of catalysts is described here in brief. Supported Pt catalysts were prepared by wet impregnation using $\mathrm{H}_{2} \mathrm{PtCl}_{6} \cdot 6 \mathrm{H}_{2} \mathrm{O}$ as a metal precursor and P-containing activated charcoal (PAC) and activated carbon (AC) as supports, which were monometallic $\mathrm{Pt} / \mathrm{PAC}$ and bimetallic $\mathrm{Co} / \mathrm{Pt} / \mathrm{PAC}$ and $\mathrm{Co} / \mathrm{Pt} / \mathrm{AC}$ samples, the latter being prepared by loading $\mathrm{Co}$ from $\mathrm{Co}\left(\mathrm{NO}_{3}\right)_{2} \cdot 6 \mathrm{H}_{2} \mathrm{O}$ to reduced $\mathrm{Pt} / \mathrm{PAC}$ and $\mathrm{Pt} / \mathrm{AC}$, respectively. In addition, another bimetallic $\mathrm{CoPt} / \mathrm{PAC}$ sample was prepared by co-impregnation and a monometallic $\mathrm{Co} / \mathrm{PAC}$ one by impregnation. The final thermal treatment of those samples was reduction with $\mathrm{H}_{2}$ at $385^{\circ} \mathrm{C}$ and $450^{\circ} \mathrm{C}$ for Pt-containing and monometallic Co samples, respectively. The catalysts included $\mathrm{Pt}$ in a fixed amount of $0.50 \mathrm{wt} .-\%$ and $\mathrm{Co}$ in different amounts of $0.075,0.15$, and $0.30 \mathrm{wt} .-\%$. The molar ratio of $\mathrm{Co} / \mathrm{Pt}$ was 1 at a Co loading of $0.15 \mathrm{wt} .-\%$. The detailed catalyst preparation procedures and conditions used are described below in the Experimental Section.

\subsection{Catalytic Performance}

The performance of those Pt catalysts prepared was tested in liquid phase selective hydrogenation of 3-nitrostyrene (NS) in toluene (Scheme 1), in which 3-aminostyrene (AS), 3-ethylnitrobenzene (ENB), and 3-ethylaniline (EA) would be formed via hydrogenation of nitro group, vinyl one, and both ones, respectively. The product selectivity, as well as the rate of NS conversion, was observed to depend on the catalysts used. Table 1 gives the performance of several monometallic and bimetallic catalysts. $\mathrm{Pt}$ on PAC was active and selective to the formation of AS with a selectivity of $81 \%$ (entry 2) while Co was inactive (entry 1$)$. The addition of inactive Co to $\mathrm{Pt} / \mathrm{PAC}(\mathrm{Co} / \mathrm{Pt}=1)$ decreased the rate of NS 
conversion but increased the AS selectivity to $94 \%$ (entry 3 and entry 4). With this catalyst, the nitro group of NS was more selectively hydrogenated to AS than the vinyl group of NS and the vinyl group of AS was little hydrogenated to the final product of EA. However, when AC containing no P species on its surface was used instead of $\mathrm{PAC}$, the modified $\mathrm{Co} / \mathrm{Pt} / \mathrm{AC}$ catalyst had a higher activity but a low selectivity to AS, with which the selectivity to either ENB or EA was larger (entry 5). Even when PAC was used but $\mathrm{Pt}$ and $\mathrm{Co}$ were loaded simultaneously by co-impregnation, larger NS conversion and smaller AS selectivity were observed (entry 6), similar to $\mathrm{Co} / \mathrm{Pt} / \mathrm{AC}$, compared to $\mathrm{Co} / \mathrm{Pt} / \mathrm{PAC}$. That is, the influence of support materials and metal impregnation methods was significant in determining the catalytic activity and the product selectivity.

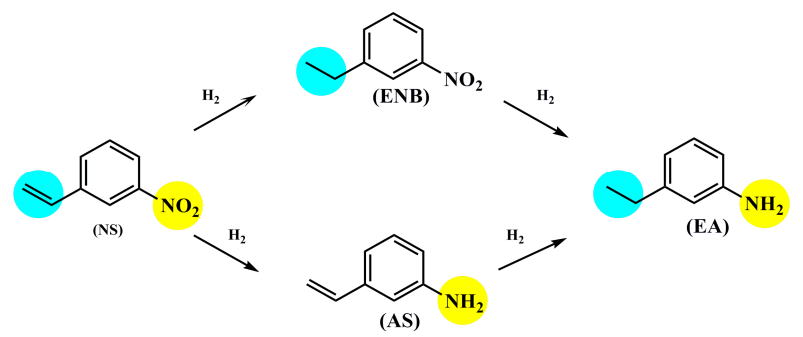

Scheme 1. Reaction pathways for the hydrogenation of 3-nitrostyrene (NS).

Table 1. Hydrogenation of 3-nitrostyrene (NS) over different catalysts.

\begin{tabular}{cccccccc}
\hline \multirow{2}{*}{ Entry } & \multirow{2}{*}{ Catalysts } & \multirow{2}{*}{ Time (h) } & Conversion (\%) & \multicolumn{4}{c}{ Selectivity (\%) } \\
\cline { 5 - 8 } & & & & AS & ENB & EA & Others $^{\text {a }}$ \\
\hline 1 & Co/PAC & 6 & 0 & 0 & 0 & 0 & 0 \\
2 & Pt/PAC & 8 & 94 & 81 & 2 & 15 & 2 \\
3 & Co/Pt/PAC & 10 & 84 & 94 & 0 & 2 & 4 \\
4 & $\mathrm{Co} / \mathrm{Pt} / \mathrm{PAC}$ & 14 & 97 & 94 & 1 & 2 & 3 \\
5 & $\mathrm{Co} / \mathrm{Pt} / \mathrm{AC}$ & 1 & 95 & 15 & 24 & 46 & 15 \\
6 & $\mathrm{CoPt} / \mathrm{PAC}$ & 1 & 88 & 12 & 35 & 40 & 13 \\
\hline
\end{tabular}

Reaction conditions: $40 \mathrm{mg}$ catalyst (Pt loading was $0.50 \mathrm{wt} .-\%$ and $\mathrm{Co}$ loading was $0.15 \mathrm{wt} .-\%, \mathrm{Co} / \mathrm{Pt}=1$ ), $5 \mathrm{~mL}$ toluene, $0.5 \mathrm{mmol} \mathrm{NS}, 100{ }^{\circ} \mathrm{C}, 4 \mathrm{MPa} \mathrm{H}_{2} .{ }^{a}$ Others are traces of 3-hydroxylamine styrene, 3-azostyrene, 3-azoxystyrene, and 3-vinylnitrosobenzene.

Then, the influence of Co loading was examined using $\mathrm{Co} / \mathrm{Pt} / \mathrm{PAC}$ catalyst that was selective to the formation of AS. The results collected by using Co/Pt values of $0.5,1.0$, and 2.0 are given in Table 2 . Although a small added amount of Co $(0.075 \mathrm{wt.} . \%)$ decreased the rate of NS conversion by a factor of about 2, the selectivity to AS was enhanced to $95 \%$ from $81 \%$ (entry 2). Further increase in the Co loading did not change the high AS selectivity but increased the catalytic activity (entries 3,4 ). The rate of NS conversion with 0.30 wt.-\% Co-loaded Pt/PAC was comparable to that with Co-unmodified $\mathrm{Pt} / \mathrm{PAC}$ (entries 1, 4). The product selectivity with Co/Pt/PAC catalysts was not observed to change with the NS conversion. The time-selectivity-conversion relation measured for a selected catalyst of 0.075 wt.-\% Co-loaded Pt/PAC catalyst is given in Figure 1.

Table 2. Hydrogenation of NS over Co-modified 0.50 wt.- $\%$ Pt/PAC catalysts.

\begin{tabular}{|c|c|c|c|c|c|c|c|c|c|}
\hline \multirow{2}{*}{ Entry } & \multirow{2}{*}{$\begin{array}{l}\text { Content of } \\
\text { Co (wt.-\%) }\end{array}$} & \multirow{2}{*}{$\mathrm{Co} / \mathrm{Pt}$} & \multirow{2}{*}{ Time (h) } & \multirow{2}{*}{$\begin{array}{c}\text { Conversion } \\
(\%)\end{array}$} & \multicolumn{4}{|c|}{ Selectivity (\%) } & \multirow{2}{*}{$\begin{array}{c}\text { Average Reaction } \\
\text { Rate }\left(\mathrm{mmol}^{-1} \cdot \mathrm{g}^{-1}\right) \mathrm{b}\end{array}$} \\
\hline & & & & & AS & ENB & EA & Others $^{a}$ & \\
\hline 1 & 0 & 0 & 8 & 94 & 81 & 2 & 15 & 2 & 1.5 \\
\hline 2 & 0.075 & 0.5 & 16 & 81 & 95 & 0 & 1 & 4 & 0.7 \\
\hline 3 & 0.15 & 1 & 10 & 84 & 94 & 0 & 2 & 4 & 1.1 \\
\hline 4 & 0.30 & 2 & 8 & 81 & 92 & 0 & 4 & 4 & 1.5 \\
\hline
\end{tabular}

Reaction conditions: $40 \mathrm{mg}$ catalyst (Pt loading was $0.50 \mathrm{wt} .-\%), 5 \mathrm{~mL}$ toluene, $0.5 \mathrm{mmol} \mathrm{NS}, 100{ }^{\circ} \mathrm{C}, 4 \mathrm{MPa} \mathrm{H}_{2}{ }^{\mathrm{a}}$ Others were 3-hydroxylamine styrene, 3-azostyrene, 3-azoxystyrene, and 3-vinylnitrosobenzene. ${ }^{\mathrm{b}}$ Average reaction rate $=$ amount (mole) of NS consumed per $1 \mathrm{~g}$ catalyst per $1 \mathrm{~h}$. 

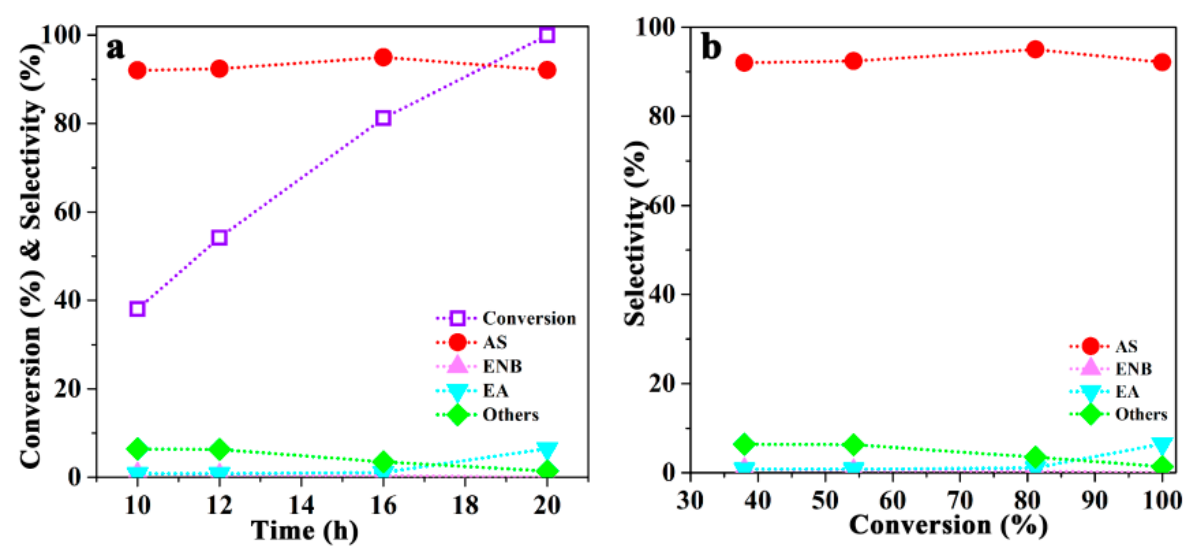

Figure 1. Catalytic performance of 0.075 wt.- $\%$ Co-loaded Pt/ P-containing activated charcoal (PAC) catalyst in selective hydrogenation of NS. The profile of Time-Conversion-Selectivity (a) and the profile of Conversion-Selectivity (b). (Reaction conditions: $40 \mathrm{mg}$ catalyst, $5 \mathrm{~mL}$ toluene, $0.5 \mathrm{mmol} \mathrm{NS}, 100{ }^{\circ} \mathrm{C}$, $4 \mathrm{MPa} \mathrm{H}_{2}$.).

\subsection{Catalyst Characterization}

The catalytic performance (activity and selectivity) of supported Pt catalysts was shown to depend significantly on Co addition, support materials (PAC, AC), and metal loading methods (successive impregnation, co-impregnation) as above-mentioned. The high AS selectivity obtained with $\mathrm{Co} / \mathrm{Pt} / \mathrm{PAC}$ catalysts attracted our attention. The catalysts were characterized by different methods to find reasons for such a high AS selectivity in NS hydrogenation, and then the roles of Co additives and P-containing groups on the surface of PAC were discussed.

The dispersion of metal particles on PAC was examined by TEM and XRD. Figure 2 gives TEM images and particle size distributions determined from them for $\mathrm{Pt} / \mathrm{PAC}, \mathrm{Co} / \mathrm{Pt} / \mathrm{PAC}$, and $\mathrm{CoPt} / \mathrm{PAC}$ samples. For the monometallic $\mathrm{Pt} / \mathrm{PAC}$ catalyst, $\mathrm{Pt}$ was finely dispersed in the form of nanoparticles with an average particle size of about $2 \mathrm{~nm}$ (Figure 2a). The addition of Co in either 0.15 or $0.30 \mathrm{wt} .-\%$ to $\mathrm{Pt} / \mathrm{PAC}$ (Pt $0.50 \mathrm{wt} . \mathrm{\%} \%$ ) increased the size of dispersed metal particles by a factor of about three, which were in the range of 4 to $10 \mathrm{~nm}$ (Figure $2 \mathrm{~b}, \mathrm{c}$ ). For those Co-modified Pt catalysts, the molar ratio of $\mathrm{Co} / \mathrm{Pt}$ was 1 or 2 . In addition, the size of metal particles in co-impregnated CoPt/PAC was about $2.5 \mathrm{~nm}$ (Figure 2d), which was similar to Pt/PAC but different from $\mathrm{Co} / \mathrm{Pt} / \mathrm{PAC}$ samples. XRD results (Figure 3) showed no detectable diffraction of metals and metal oxides probably due to small metal loading and high metal dispersion. The authors believe that Co species were likely to deposit close to or on Pt nanoparticles that already existed on PAC in advance of Co impregnation but not on PAC separately from Pt particles.

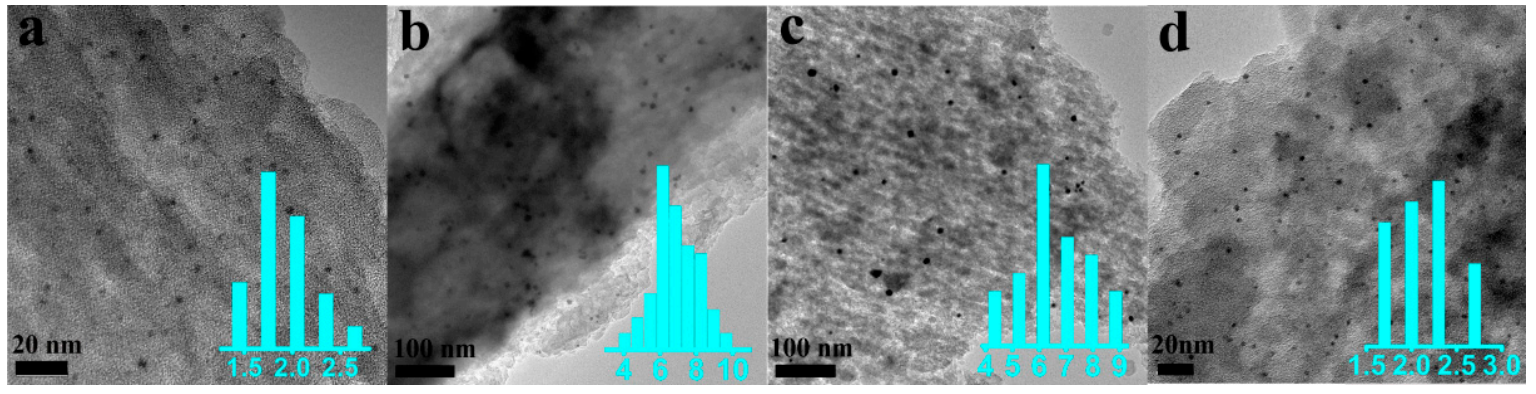

Figure 2. Transmission electron microscopy (TEM) images of $0.50 \mathrm{wt} .-\%$ Pt supported PAC catalysts: (a) Pt/PAC, (b) 0.15 wt.-\% Co-modified Pt/PAC, (c) 0.30 wt.- $\%$ Co-modified Pt/PAC and (d) CoPt/PAC (Prepared by co-impregnated, Co loading was 0.15 wt.- $\%$ ). 


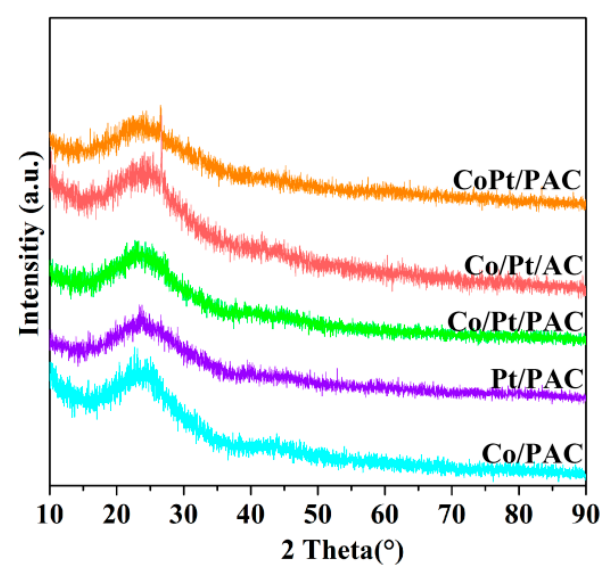

Figure 3. The X-ray powder diffraction (XRD) profiles of different catalysts. (Pt loading was 0.50 wt.-\% and Co loading was 0.15 wt.- $\%)$.

The behavior of reduction of those samples with $\mathrm{H}_{2}$ was examined by temperature programmed reduction (TPR), as shown in Figure 4. The metal-unloaded carbon support, PAC, indicated $\mathrm{H}_{2}$ consumption at 500 to $600{ }^{\circ} \mathrm{C}$, which was used for the removal of surface oxygen-containing functional groups (SOFGs including $\mathrm{PO}_{\mathrm{x}}$, explained later) on PAC. For $0.50 \mathrm{wt} . \mathrm{\%} \% \mathrm{Pt}$-loaded PAC, there were a few different states of $\mathrm{Pt}$ species and $\mathrm{H}_{2}$ consumption was detected at temperatures of 150,300 , 450 , and $550{ }^{\circ} \mathrm{C}$, which were assignable to the reduction of free $\mathrm{Pt}$ species to $\mathrm{Pt}^{0}$, the reduction of those interacting with surface acidic groups, the reduction of $\mathrm{Pt}-\mathrm{PO}_{\mathrm{x}}$ species, and the removal of SOFGs [51,52]. A broad $\mathrm{H}_{2}$ consumption was observed at temperatures of 300 to $600{ }^{\circ} \mathrm{C}$ for 0.15 wt.- $\%$ Co-loaded PAC, due to the reduction of $\mathrm{CoO}_{x}$ and $\mathrm{CoPO}_{x}$ species and SOFGs $[43,53,54]$. For a bimetallic $\mathrm{Co} / \mathrm{Pt} / \mathrm{PAC}$ catalyst $(\mathrm{Co} / \mathrm{Pt}=1)$, in which $\mathrm{Pt} / \mathrm{PAC}$ was pre-reduced at a low temperature of $150{ }^{\circ} \mathrm{C}$ and then loaded with $\mathrm{Co}$, a sharp $\mathrm{H}_{2}$ consumption peak was observed at $330{ }^{\circ} \mathrm{C}$ for the reduction of $\mathrm{CoO}_{x}$ species; in this catalyst, $\mathrm{Pt}$ species was almost reduced in advance and so metallic $\mathrm{Pt}$ species promoted the reduction of $\mathrm{CoO}_{x}$ species, lowering their reduction temperature to $330^{\circ} \mathrm{C}$ from $400{ }^{\circ} \mathrm{C}$ [43]. For another $\mathrm{CoPt} / \mathrm{PAC}$ catalyst prepared by co-impregnation, however, $\mathrm{H}_{2}$ was consumed in a wide range of temperature, similar to $\mathrm{Co} / \mathrm{PAC}$, and $\mathrm{Pt}$ had no influence on the reduction of Co species.

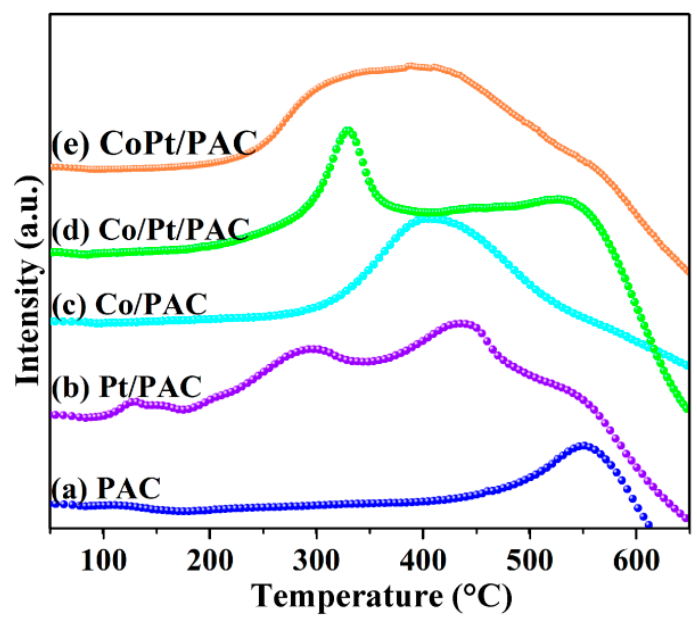

Figure 4. $\mathrm{H}_{2}$-temperature programmed reduction (TPR) profiles of PAC (a), monometallic catalysts $\mathrm{Pt} / \mathrm{PAC}(\mathbf{b}), \mathrm{Co} / \mathrm{PAC}(\mathbf{c})$, bimetallic catalysts $\mathrm{Co} / \mathrm{Pt} / \mathrm{PAC}(\mathbf{d})$, and CoPt/PAC (e). (Pt loading was 0.50 wt.- $\%$ and Co loading was $0.15 \mathrm{wt} .-\%$, the molar ratio of $\mathrm{Co} / \mathrm{Pt}$ is 1$)$.

Next, the surface of PAC support and Co-modified and unmodified Pt catalysts on PAC was examined by XPS. Co $2 p$ XPS profiles of monometallic catalysts $\mathrm{Co} / \mathrm{PC}$, bimetallic catalysts $\mathrm{Co} / \mathrm{Pt} / \mathrm{PAC}$ 
and $\mathrm{CoPt} / \mathrm{PAC}$ catalysts are shown in Figure 5. The Co $2 \mathrm{p}_{3 / 2}$ peaks of these two samples were close to $784.0 \mathrm{eV}$, indicating that the surface Co was mainly in the oxidation state of $\mathrm{Co}^{\delta+}$, possibly in the form of $\mathrm{CoO}_{\mathrm{x}}$ and $\mathrm{Co}\left(\mathrm{HPO}_{3} \mathrm{H}\right)_{2}$ [55], which was related to the re-oxidation of the reduced $\mathrm{Co}$ in air. In the case of $\mathrm{Co} / \mathrm{Pt} / \mathrm{PAC}$, the peak at a higher binding energy of $788.7 \mathrm{eV}$ was assigned to $\mathrm{Co}^{2+}$ satellite peak in the oxidized state [56]. The binding energy of about $777.3 \mathrm{eV}$ was attributed to $\mathrm{CoPO}_{\mathrm{x}}$ species $[53,55]$. In addition, only a very weak signal at $778.6 \mathrm{eV}$ assigned to $\mathrm{Co}^{0}$ was detected on the $\mathrm{Co} / \mathrm{Pt} / \mathrm{PAC}$ catalyst $(\mathrm{Co} / \mathrm{Pt}=2)$, but it was absent in the monometallic catalyst $\mathrm{Co} / \mathrm{PAC}$. Furthermore, compared with $\mathrm{Co} / \mathrm{PAC}$, the signals of $\mathrm{Co} / \mathrm{Pt} / \mathrm{PAC}$ shifted to a higher binding energy area but no binding energy shift for $\mathrm{CoPt} / \mathrm{PAC}$. The electronic states of Co indicated that almost all the Co species existed in oxidation states other than metallic states in the monometallic and bimetallic catalysts. Noteworthy, almost no Pt signal can be detected in the XPS of the $\mathrm{Co} / \mathrm{Pt} / \mathrm{PAC}$ and $\mathrm{CoPt} / \mathrm{PAC}$ catalysts due to the small $\mathrm{Pt}$ loading and coverage of Pt with Co species.

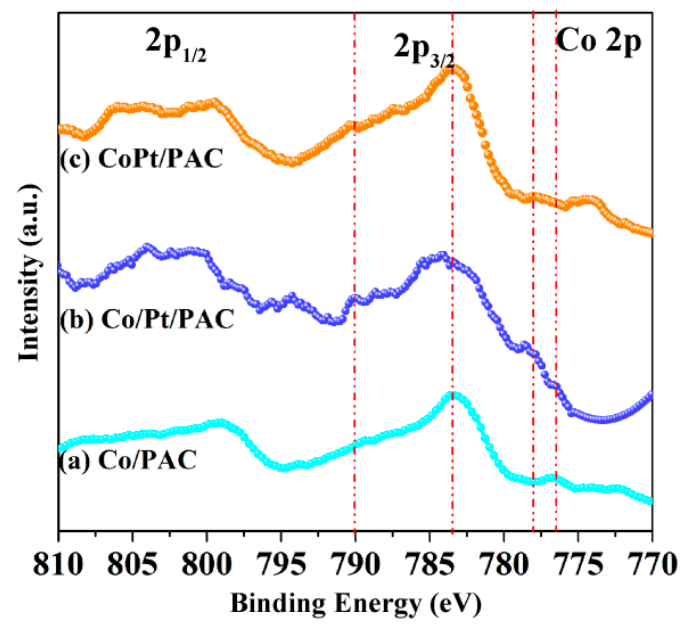

Figure 5. X-ray photoelectron spectroscopy (XPS) profiles of Co $2 \mathrm{p}$ of $\mathrm{Co} / \mathrm{PAC}(\mathbf{a}), \mathrm{Co} / \mathrm{Pt} / \mathrm{PAC}(\mathbf{b})$ (Co loading was $0.30 \mathrm{wt} .-\%$ ) and CoPt/PAC (c) (Co loading was $0.15 \mathrm{wt} . \mathrm{\%} \%$ )(Pt loading was $0.50 \mathrm{wt} .-\%$ for all the catalyst).

P in the supports had significant influence on the state of metals loaded on them. P 2p XPS showed the various $\mathrm{P}$ species in the monometallic and bimetallic catalysts as seen in Figure 6. The proportions of each $\mathrm{P}$ species are also given in Table 3. The deconvolution of the P $2 \mathrm{p}$ peaks was used to evaluate the four contributions at $130.6 \mathrm{eV}(\mathrm{P}-1), 133.3 \mathrm{eV}$ (P-2), $134.5 \mathrm{eV}$ (P-3), and $135.9 \mathrm{eV}$ (P-4), which were related to the phosphine, phosphinic, phosphite, and phosphate, respectively $[57,58]$. The more coordinated oxygen atoms the P species coordinated, the higher the binding energy was. P-1 existed in all the monometallic and bimetallic catalysts although the amount is signifiantly less. The content of $\mathrm{P}-2$ species in the $\mathrm{Co} / \mathrm{Pt} / \mathrm{PAC}$ catalysts was larger than that in $\mathrm{Pt} / \mathrm{PAC}, \mathrm{Co} / \mathrm{PAC}$, and $\mathrm{CoPt} / \mathrm{PAC}$, and it was also influenced by the $\mathrm{Co} / \mathrm{Pt}$ ratio in the catalysts (Table 3). The addition of Co increased the content of low-coordinated $\mathrm{P}$ species of phosphinic (P-2 species) in $\mathrm{Co} / \mathrm{Pt} / \mathrm{PAC}$ catalysts but not in $\mathrm{CoPt} / \mathrm{PAC}$. Furthermore, $\mathrm{P}-4$ species in $\mathrm{Co} / \mathrm{PAC}$ and $\mathrm{CoPt} / \mathrm{PAC}$ catalysts showed the largest percentage of $31.9 \%$ and $27.4 \%$, compared to $\mathrm{Pt} / \mathrm{PAC}(5.3 \%)$ and $\mathrm{Co} / \mathrm{Pt} / \mathrm{PAC}(<4 \%)$. It is proposed that the $\mathrm{CoO}_{\mathrm{x}}$ and $\mathrm{CoPO}_{\mathrm{x}}$ in the $\mathrm{Co} / \mathrm{Pt} / \mathrm{PAC}$ were dispersed uniformly on the $\mathrm{Pt}$, which caused the transformation of P-4 to P-2 during the reduction. The influence of P species on the hydrogenation selectivity to $-\mathrm{NO}_{2}$ group of NS will be discussed in detail in the following section. 

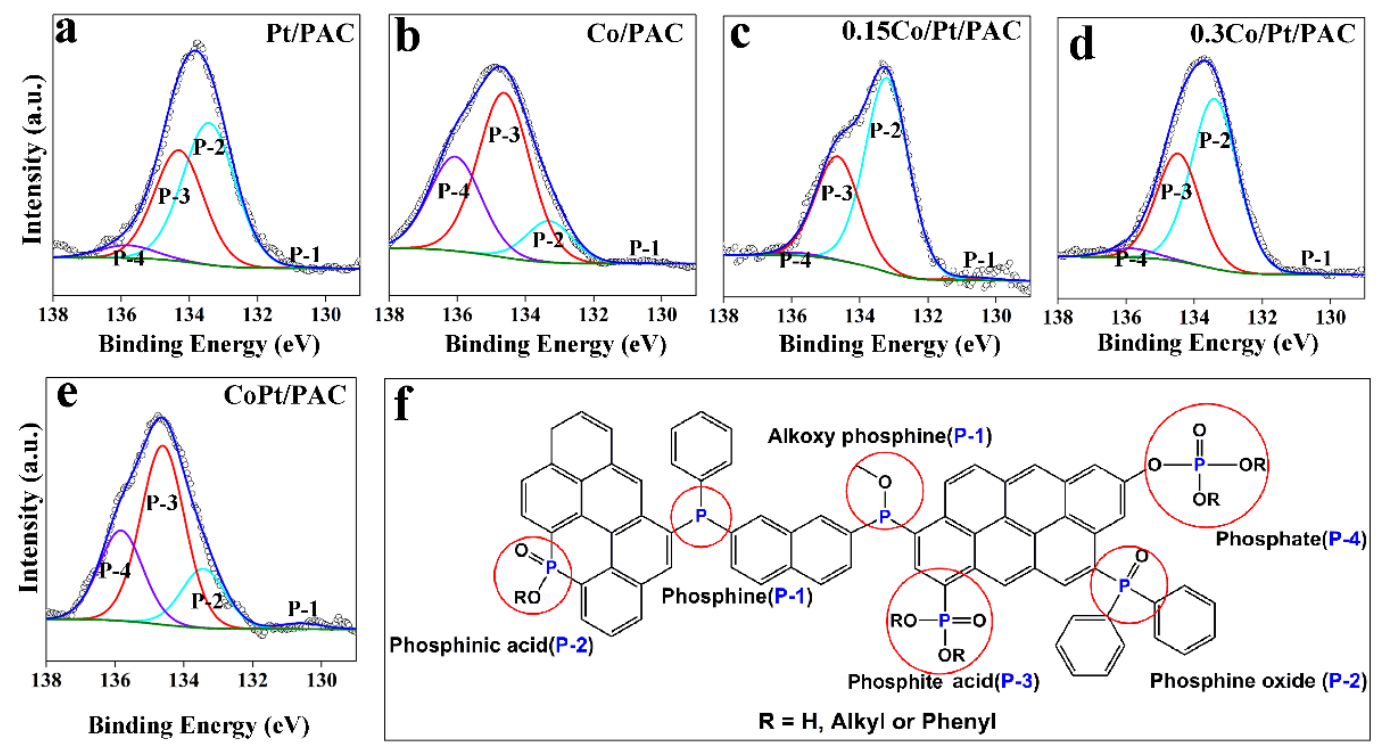

Figure 6. P 2p XPS spectra of Pt/PAC (a), Co/PAC (b), 0.15 wt.-\% Co-modified Pt/PAC (c), 0.30 wt.-\% Co-modified Pt/PAC (d), CoPt/PAC (e) (Co loading was 0.15 wt.-\%), and (f) Types of P-containing functional groups in the activated charcoal.

Table 3. The content of different P-containing functional groups over bimetallic and monometallic catalysts.

\begin{tabular}{|c|c|c|c|c|c|c|}
\hline \multirow{2}{*}{ Entry } & \multirow{2}{*}{ Catalysts $^{\text {a }}$} & \multirow{2}{*}{$\begin{array}{c}\text { Co/Pt Molar } \\
\text { Ratio }\end{array}$} & \multicolumn{4}{|c|}{ Content of P-containing Functional Groups (\%) } \\
\hline & & & $\begin{array}{l}\text { Phosphine } \\
\text { (P-1) }\end{array}$ & $\begin{array}{c}\text { Phosphinic } \\
\text { (P-2) }\end{array}$ & $\begin{array}{c}\text { Phosphite } \\
\text { (P-3) }\end{array}$ & $\begin{array}{c}\text { Phosphate } \\
\text { (P-4) }\end{array}$ \\
\hline 1 & $\mathrm{Pt} / \mathrm{PAC}$ & 0 & 0.3 & 54.4 & 40.1 & 5.2 \\
\hline 2 & $0.15 \mathrm{Co} / \mathrm{PAC}$ & $\infty$ & 0.1 & 12.4 & 55.6 & 31.9 \\
\hline 3 & $0.15 \mathrm{Co} / \mathrm{Pt} / \mathrm{PAC}$ & 1 & 0.5 & 64.3 & 34.3 & 0.9 \\
\hline 4 & $0.30 \mathrm{Co} / \mathrm{Pt} / \mathrm{PAC}$ & 2 & 0.7 & 60.2 & 35.8 & 3.3 \\
\hline 5 & $0.15 \mathrm{CoPt} / \mathrm{PAC}$ & 1 & 0.2 & 18.0 & 54.4 & 27.4 \\
\hline
\end{tabular}

${ }^{a}$ Pt loading was 0.50 wt.- $\%$ for all catalysts; Co loading was given before Co in wt.- $\%$.

Furthermore, the adsorption of NS substrate was examined by in-situ DRIFTS for Co/Pt/PAC and $\mathrm{CoPt} / \mathrm{PAC}$ that were selective to AS and to ENB and EA, respectively. These samples contained $\mathrm{Pt}$ and $\mathrm{Co}$ in 0.50 and $0.15 \mathrm{wt} .-\%$, respectively $(\mathrm{Co} / \mathrm{Pt}=1)$ and were both reduced by $\mathrm{H}_{2}$ at $385^{\circ} \mathrm{C}$. Figure 7 gives in-situ DRIFTS spectra recorded at $150{ }^{\circ} \mathrm{C}$ just after the NS adsorption and after the removal of physically adsorbed NS molecules by passing a He gas stream for $2 \mathrm{~h}$. Two absorption bands were observed at 1350 and $1530 \mathrm{~cm}^{-1}$ assignable to $v_{\mathrm{as}}\left(\mathrm{NO}_{2}\right)$ and $v_{\mathrm{s}}\left(\mathrm{NO}_{2}\right)$ of the nitro group of NS [59-62] and three overlapped bands at 2870 to $3000 \mathrm{~cm}^{-1}$ due to $-\mathrm{CH}$ of $=\mathrm{C}-\mathrm{H}$ on the benzene ring $[63,64]$. These absorption bands remained unchanged after passing He gas over the sample, through which, however, the absorption band at $3090 \mathrm{~cm}^{-1}$ disappeared due to $(-\mathrm{CH})$ of the vinyl group stretching vibration [65]. That is, the substrate NS was adsorbed with its nitro group on the catalyst group more strongly than with its vinyl group. For CoPt/PAC catalyst, in contrast, those absorption bands were detected even after the sample was purged by He due to the nitro and vinyl groups of NS. Therefore, NS was adsorbed with the nitro and vinyl groups on CoPt/PAC while preferentially with the nitro group on $\mathrm{Co} / \mathrm{Pt} / \mathrm{PAC}$. This difference in the NS adsorption behavior is an important factor responsible for the differences observed in the product selectivity in the NS hydrogenation between the two catalysts. 

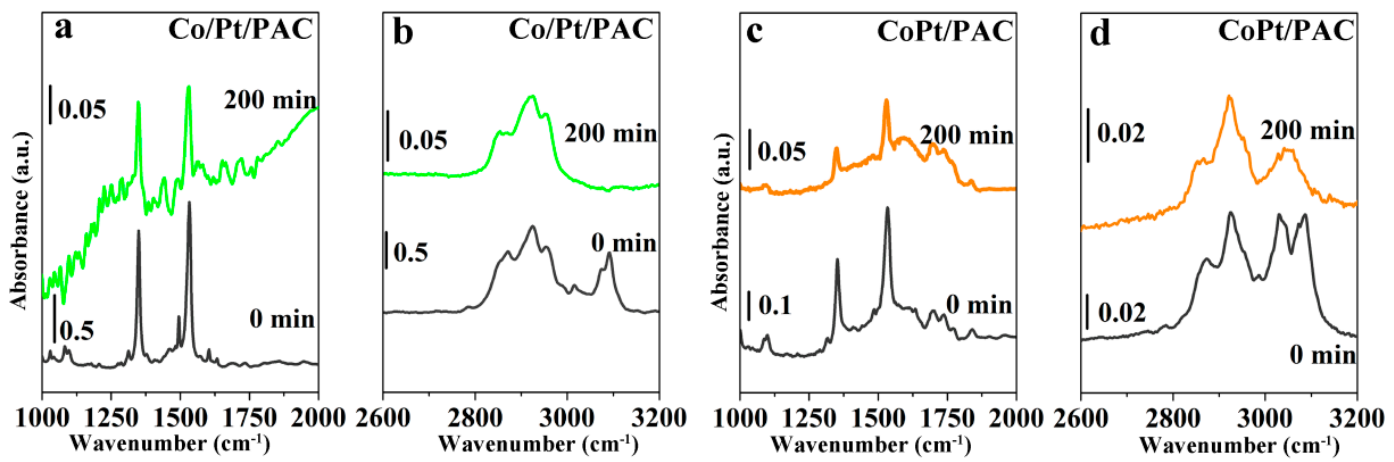

Figure 7. In-situ diffuse reflectance infrared Fourier transform spectroscopy (DRIFTS) adsorption spectra of NS over Co/Pt/PAC (a,b) and CoPt/PAC (c,d). (Pt loading was 0.50 wt.- $\%$ and Co loading is 0.15 wt.- $\%)$.

\section{Roles of Co Additive and Surface P-containing Species}

The present results demonstrate that the high selectivity to AS in NS hydrogenation can be achieved by $\mathrm{Co} / \mathrm{Pt} / \mathrm{PAC}$ catalyst but not by $\mathrm{Pt} / \mathrm{PAC}, \mathrm{CoPt} / \mathrm{PAC}$, and $\mathrm{Co} / \mathrm{Pt} / \mathrm{AC}$ ones. That is, both $\mathrm{Co}$ additive and $\mathrm{P}$-containing carbon are requisites, and $\mathrm{Co}$ is required to be loaded by successive impregnation to pre-reduced Pt/PAC. The high AS selectivity results from the preferential adsorption of NS with its nitro group on the catalyst, indicating that the surface structure of supported bimetallic metal particles should be beneficial for such selective adsorption. According to the present TEM and XPS results and those reported in previous work on Pt/PAC, a possible structure of the supported $\mathrm{Pt}$ particles that interact with and are modified by $\mathrm{Co}$ and $\mathrm{P}$ species is proposed, as in Figure 8 . The authors have previously shown that the selectivity of NS hydrogenation over carbon-supported Pt catalyst is switched, becoming selective to AS, by the decoration of $\mathrm{Pt}$ particles with $\mathrm{PO}_{\mathrm{x}}$ species. The surface of $\mathrm{Pt}$ particles is covered in part by $\mathrm{PO}_{x}$ species and the resulting $\mathrm{Pt}-\mathrm{PO}_{\mathrm{x}}$ interface favors the adsorption of NS with its polar nitro group rather than the non-polar vinyl group. This results in the selective hydrogenation of the nitro group of NS yielding AS, the vinyl group of which is not adsorbed and hydrogenated to the final product of EA. The partial decoration with $\mathrm{PO}_{\mathrm{x}}$ decreases the number of active $\mathrm{Pt}$ sites exposed on the surface of $\mathrm{Pt}$ particles, decreasing the overall rate of NS hydrogenation. In a monometallic Pt/PAC catalyst using a P-containing support, some Pt species interact with $\mathrm{PO}_{\mathrm{x}}$ ones at the Pt particle-support interface and this interfacial layer assists the adsorption of NS with its nitro group rather than vinyl group (Figure 8). In addition, such $\mathrm{Pt}-\mathrm{PO}_{\mathrm{x}}$ interactions should affect the surface electronic properties of Pt particles. Then, the adsorption and hydrogenation of nitro group of $\mathrm{NS}$ are likely to occur selectively on this $\mathrm{Pt} / \mathrm{PAC}$ catalyst, as reported previously [50]. For the $\mathrm{Pt}-\mathrm{PO}_{\mathrm{x}}$ interactions, P-2 type of surface P species is important (Table 3). When Co is added to pre-reduced $\mathrm{Pt} / \mathrm{PAC}$ catalyst, it tends to deposit close to and/or on the Pt particles and to increase the amount of P-2 type $\mathrm{P}$ species. Then, the addition of $\mathrm{Co}$ should increase the number of $\mathrm{Pt}$ species interacting with the $\mathrm{PO}_{\mathrm{x}}$ ones at the $\mathrm{Pt}$ particle-support interface and cover the surface of $\mathrm{Pt}$ particles to some extent. The electronic properties of surface $\mathrm{Pt}$ species would also be influenced by the presence of more $\mathrm{PO}_{\mathrm{x}}$ species at the interface and some $\mathrm{CoO}_{\mathrm{x}}$ species on the Pt particles. These factors should be responsible for a larger AS selectivity via hydrogenation of nitro group of NS observed in the Co-modified Pt/PAC catalyst. For $\mathrm{CoPt} / \mathrm{PAC}$ catalyst prepared by co-impregnation, such a modification of $\mathrm{Pt}$ particles by $\mathrm{PO}_{\mathrm{x}}$ and/or $\mathrm{CoO}_{\mathrm{x}}$ is even less significant. It is likely that $\mathrm{CoO}_{\mathrm{x}}$ species interact with $\mathrm{PO}_{\mathrm{x}}(\mathrm{P}-3)$ more strongly than that of $\mathrm{Pt}$ with $\mathrm{PO}_{\mathrm{x}}(\mathrm{P}-2)$, resulting in less or no significant modification of the surface of Pt particles by these species. Then, the CoPt/PAC catalyst is not selective to the formation of AS (Table 1). 


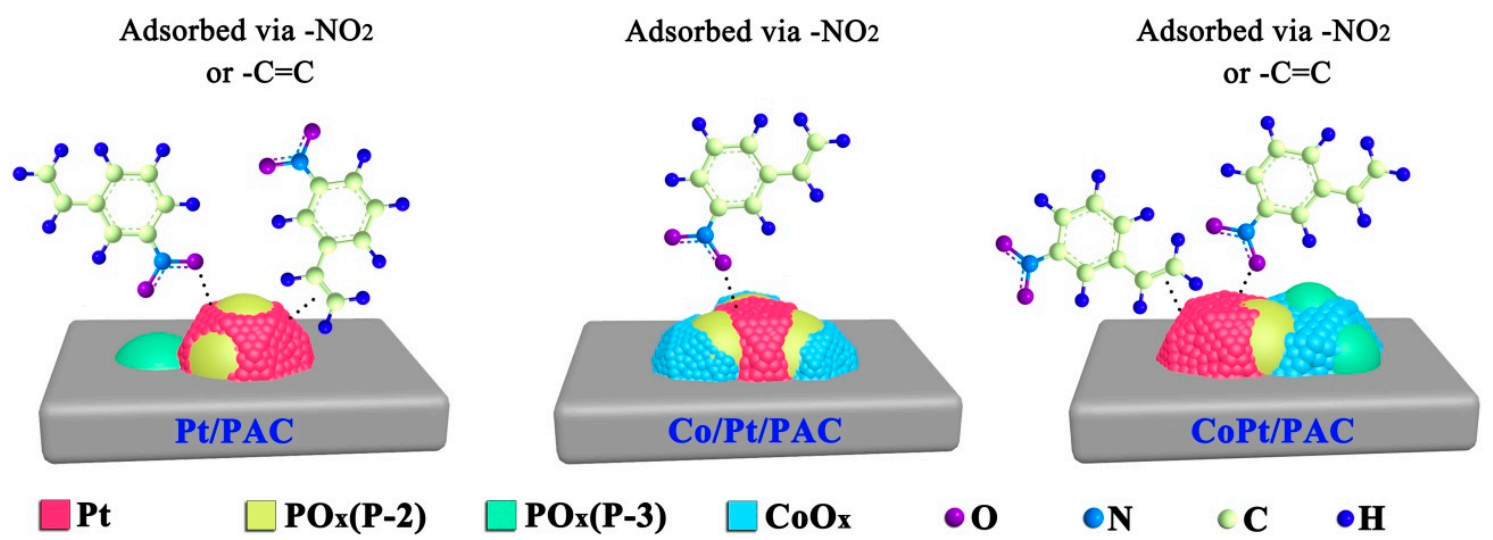

Figure 8. Possible structures of $\mathrm{Pt} / \mathrm{PAC}, \mathrm{Co} / \mathrm{Pt} / \mathrm{PAC}$ and $\mathrm{CoPt} / \mathrm{PAC}$ catalysts and different modes of adsorption of NS on their metal particles. (Red: Pt, Yellow: $\mathrm{PO}_{\mathrm{x}}(\mathrm{P}-2)$, Green: $\mathrm{PO}_{\mathrm{x}}(\mathrm{P}-3), \mathrm{Blue}_{\mathrm{CoO}}$ ).

\section{Experimental Section}

\subsection{Materials}

Commercially available reagents, 3-nitrostyrene (Acros; $\geq 97 \%$ ), $\mathrm{H}_{2} \mathrm{PtCl}_{6} \cdot 6 \mathrm{H}_{2} \mathrm{O}$ (Shanghai Jiu Ling, Shanghai, China; $\geq 99.9 \%$ ), $\mathrm{Co}\left(\mathrm{NO}_{3}\right)_{2} \cdot 6 \mathrm{H}_{2} \mathrm{O}$ (Aladin, Shanghai, China; $\geq 99.9 \%$ ), toluene and ethanol (Beijing chemicals, Beijing, China; $\geq 99.9 \%$ ) were used as received. The P-containing activated charcoal (Sigma-Aldrich, St. Louis, MO, USA, untreated powder, 100-400 mesh, C3345, 1.7 wt.- $\%$ phosphor in weight percentage, surface area is $1262 \mathrm{~m}^{2} / \mathrm{g}$ ) and activated coconut carbon without $\mathrm{P}$ elements (Fujian XinSen, Nanping, China, C $\geq 99.0 \%$, ash $\leq 0.50 \%$, bulk density $0.32-0.4 \mathrm{~kg} / \mathrm{L}$, surface area is $1851 \mathrm{~m}^{2} / \mathrm{g}$ ) were used as raw carbon materials, which are abbreviated as PAC and AC.

\subsection{Catalyst Preparation}

Supported monometallic (Pt/PAC, $\mathrm{Co} / \mathrm{PAC})$ and bimetallic $(\mathrm{Co} / \mathrm{Pt} / \mathrm{PAC}, \mathrm{Co} / \mathrm{Pt} / \mathrm{AC}, \mathrm{CoPt} / \mathrm{PAC})$ catalysts were prepared by the wet-impregnation method. In the synthesis of $0.50 \mathrm{wt} . \mathrm{\%} \% \mathrm{Pt} / \mathrm{PC}$ catalyst, $13.3 \mathrm{mg} \mathrm{H} \mathrm{H}_{2} \mathrm{PtCl}_{6} \cdot 6 \mathrm{H}_{2} \mathrm{O}$ was dissolved in $10 \mathrm{~mL}$ ethanol, and then $1.0 \mathrm{~g}$ carbon support was added to form a slurry mixture. The slurry was dried at $80^{\circ} \mathrm{C}$ in a water bath with stirring and then kept at $80^{\circ} \mathrm{C}$ in an oven overnight. Finally, the sample was reduced in an $\mathrm{H}_{2}$ stream at $385^{\circ} \mathrm{C}$ for $2 \mathrm{~h}$. Similarly, Co was impregnated to PAC from $\mathrm{Co}\left(\mathrm{NO}_{3}\right)_{2}$, calcined in $\mathrm{N}_{2}$ at $300^{\circ} \mathrm{C}$ for $2 \mathrm{~h}$, and then reduced in $\mathrm{H}_{2}$ at $450{ }^{\circ} \mathrm{C}$ for $2 \mathrm{~h}$. For bimetallic $\mathrm{Co} / \mathrm{Pt} / \mathrm{PAC}$ and $\mathrm{Co} / \mathrm{Pt} / \mathrm{AC}$, a given amount of Co precursor ethanol solution was added drop by drop to a monometallic $\mathrm{Pt}$ sample that was pre-reduced at $150{ }^{\circ} \mathrm{C}$ for $2 \mathrm{~h}$ and the sample obtained was dried at $80^{\circ} \mathrm{C}$, calcined in $\mathrm{N}_{2}$ at $300^{\circ} \mathrm{C}$, and then reduced in $\mathrm{H}_{2}$ at $385^{\circ} \mathrm{C}$ for $2 \mathrm{~h}$. Another bimetallic CoPt/PAC was prepared by co-impregnation using the same metal precursors in ethanol. After co-impregnation, the bimetallic sample was calcined in $\mathrm{N}_{2}$ at $300{ }^{\circ} \mathrm{C}$ and then reduced in $\mathrm{H}_{2}$ at $385^{\circ} \mathrm{C}$ for $2 \mathrm{~h}$. After the above-mentioned reduction and cooling to ambient temperature, all the Pt containing catalysts were purged with $\mathrm{N}_{2}$ for $30 \mathrm{~min}$ and then stored in air before use, and the Co/PAC catalyst was used directly after purging with $\mathrm{N}_{2}$.

\subsection{Characterization}

The monometallic and bimetallic catalysts so prepared were characterized by the following methods. Transmission electron microscopy (TEM) images were collected on a JEOL (Tokyo, Japan) JEM-2010 instrument operated at an accelerating voltage of $200 \mathrm{kV}$. X-ray photoelectron spectroscopy (XPS) measurements were carried on VG Microtech (Eugene, OR, USA) 3000 Multilab without sputtering. X-ray powder diffraction (XRD) measurements were carried on a Bruker (Bremen, Germany) D8 ADVANCE diffractometer, using $\mathrm{Cu} \mathrm{K} \alpha$ radiation $(\lambda=0.154 \mathrm{~nm})$. Temperature programmed reduction (TPR) using $\mathrm{H}_{2}$ was measured on Micromeritics AutoChem (Norcross, GA, USA) II 2920. For $\mathrm{H}_{2}$-TPR, a sample $(50 \mathrm{mg})$ was treated with an Ar stream $(50 \mathrm{~mL} / \mathrm{min})$ at $100{ }^{\circ} \mathrm{C}$ for $1 \mathrm{~h}$ to remove $\mathrm{H}_{2} \mathrm{O}$ and 
cooled to $50^{\circ} \mathrm{C}$. Then, the sample was heated at $5{ }^{\circ} \mathrm{C} / \mathrm{min}$ to $700{ }^{\circ} \mathrm{C}$ in a stream of $10 \% \mathrm{H}_{2}$ in $\mathrm{Ar}$ at a flow rate of $50 \mathrm{~mL} / \mathrm{min}$. The amount of $\mathrm{H}_{2}$ consumed was measured by a gas chromatograph with a thermal conductivity detector. The adsorption of 3-nitrostyrene was examined by in situ diffuse reflectance infrared Fourier transform spectroscopy (DRIFTS) on Thermo Scientific Nicolet (Waltham, MA, USA) 6700 Fourier transform infrared spectroscopy. A catalyst sample was reduced in an FTIR cell with 10\% $\mathrm{H}_{2} / \mathrm{Ar}$ mixture $(30 \mathrm{~mL} / \mathrm{min})$ at $385^{\circ} \mathrm{C}$ for $30 \mathrm{~min}$ and then cooled to $30^{\circ} \mathrm{C}$. The cell was purged with a He stream $(30 \mathrm{~mL} / \mathrm{min})$ for $30 \mathrm{~min}$, and the background spectrum was recorded. After the addition of $40 \mu \mathrm{L}$ substrate $\left(0.5 \mathrm{M}\right.$ in toluene) to the sample, the cell was heated to $150^{\circ} \mathrm{C}$ slowly while passing heat $30 \mathrm{~mL} / \mathrm{min}$. The spectrum was recorded at $150{ }^{\circ} \mathrm{C}$ every $30 \mathrm{~min}$ until all the physically adsorbed species were removed.

\subsection{Hydrogenation}

The catalytic performances of monometallic and bimetallic catalysts were tested for the selective hydrogenation of NS using a $50 \mathrm{~mL}$ stainless steel autoclave with an inner Teflon coating. For a typical catalytic reaction, $0.5 \mathrm{mmol} \mathrm{NS}$ and $40 \mathrm{mg}$ catalyst were mixed in $5 \mathrm{~mL}$ toluene. The reactor was sealed and purged with $1 \mathrm{MPa} \mathrm{H}_{2}$ three times. And then $4 \mathrm{MPa}_{2}$ introduced to the reactor after preheating at $100{ }^{\circ} \mathrm{C}$ for $20 \mathrm{~min}$. The products were analyzed by gas chromatography (Shimadzu, Kyoto, Japan, 2010) equipped with a capillary column (Restek (Bellefonte, PA, USA) Rtx-5 $30 \mathrm{~m} \times 0.25 \mathrm{~mm} \times 0.25 \mu \mathrm{m}$ ) and a flame ionization detector (FID).

\section{Conclusions}

The product selectivity in liquid phase NS hydrogenation over supported Pt catalyst can be controlled by using P-containing carbon support (PAC) and Co additive, which enhance the selectivity to the hydrogenation of its nitro group compared to the vinyl group, yielding AS in a high selectivity. There is an interfacial layer of $\mathrm{Pt}-\mathrm{PO}_{\mathrm{x}}$ on the surface of supported $\mathrm{Pt}$ particles and this layer is beneficial for the preferential adsorption of the substrate molecule with its polar nitro group and its subsequent hydrogenation to AS. The addition of Co species influences the nature of surface P species on PAC and assists the formation of $\mathrm{Pt}-\mathrm{PO}_{\mathrm{x}}$ interfacial area on the surface of $\mathrm{Pt}$ particles. The modification of the surface of $\mathrm{Pt}$ particles with $\mathrm{PO}_{\mathrm{x}}$ species decreases the number of active $\mathrm{Pt}^{0}$ sites, and so causes a reduction in the rate of NS hydrogenation. The promotional effect of surface $\mathrm{P}$ and Co additive species on the AS selectivity appears for $\mathrm{Co} / \mathrm{Pt} / \mathrm{PAC}$ catalyst prepared by successive impregnation of $\mathrm{Pt}$ and then Co. No promotional effect is unlikely for CoPt/PAC prepared by co-impregnation, which does not produce a surface on Pt particles favoring the preferential adsorption of NS with its nitro group. The product selectivity with CoPt/PAC is similar to that with monometallic Pt catalyst on P-free AC support.

Author Contributions: Conceptualization, Q.W. and C.Z.; Data curation, Q.W.; Formal analysis, Q.W. and C.Z.; Funding acquisition, C.Z. and F.Z.; Project administration, F.Z.; Supervision, C.Z. and F.Z.; Validation, Q.W., W.L. and H.C.; Writing—original draft, Q.W.; Writing—review and editing, C.Z., M.A. and F.Z.

Funding: This research was funded by National Program on Key Research Project, 2016YFA0602900; National Natural Science Foundation of China, 21872134, 21473179; International Cooperation Project of Jilin Province, 20170414012GH; the Youth Innovation Promotion Association, 2014203; Chinese Academy of Science, and CAS President's International Fellowship Initiative (PIFI) 2018CV0012, Chinese Academy of Science.

Conflicts of Interest: The authors declare no conflict of interest.

\section{References}

1. Cao, Y.; Mao, S.; Li, M.; Chen, Y.; Wang, Y. Metal/porous carbon composites for heterogeneous catalysis: Old catalysts with improved performance promoted by N-doping. ACS Catal. 2017, 7, 8090-8112. [CrossRef]

2. Lin, R.; Albani, D.; Fako, E.; Kaiser, S.K.; Safonova, O.V.; López, N.; Pérez-Ramírez, J. Design of single gold atoms on nitrogen-doped carbon for molecular recognition in alkyne semi-hydrogenation. Angew. Chem. Int. Ed. 2019, 58, 504-509. [CrossRef] [PubMed] 
3. Li, J.; Tu, D.; Li, Y.; Wang, W.; Yu, Q.; Yang, J.; Lu, J. Co-N-doped carbon nanotubes supported on diatomite for highly efficient catalysis oxidative carbonylation of amines with CO and air. Appl. Catal. A Gen. 2018, 549, 112-116. [CrossRef]

4. Hu, X.; Long, Y.; Fan, M.; Yuan, M.; Zhao, H.; Ma, J.; Dong, Z. Two-dimensional covalent organic frameworks as self-template derived nitrogen-doped carbon nanosheets for eco-friendly metal-free catalysis. Appl. Catal. B Environ. 2019, 244, 25-35. [CrossRef]

5. Ruiz-García, C.; Heras, F.; Calvo, L.; Alonso-Morales, N.; Rodriguez, J.J.; Gilarranz, M.A. Platinum and $\mathrm{N}$-doped carbon nanostructures as catalysts in hydrodechlorination reactions. Appl. Catal. B Environ. 2018, 238, 609-617. [CrossRef]

6. Gao, Y.; Zhao, H.; Chen, D.; Chen, C.; Ciucci, F. In situ synthesis of mesoporous manganese oxide/sulfur-doped graphitized carbon as a bifunctional catalyst for oxygen evolution/reduction reactions. Carbon 2015, 94, 1028-1036. [CrossRef]

7. Yang, S.; Peng, L.; Oveisi, E.; Bulut, S.; Sun, D.T.; Asgari, M.; Trukhina, O.; Queen, W.L. MOF-derived cobalt phosphide/carbon nanocubes for selective hydrogenation of nitroarenes to anilines. Chem. Eur. J. 2018, 24, 4234-4238. [CrossRef] [PubMed]

8. Berenguer, A.; Sankaranarayanan, T.M.; Gómez, G.; Moreno, I.; Coronado, J.M.; Pizarro, P.; Serrano, D.P. Evaluation of transition metal phosphides supported on ordered mesoporous materials as catalysts for phenol hydrodeoxygenation. Green Chem. 2016, 18, 1938-1951. [CrossRef]

9. Sweeny, N.P.; Rohrer, C.S.; Brown, O.W. Dinickel phosphide as a heterogeneous catalyst for the vapor phase reduction of nitrobenzene with hydrogen to aniline and water. J. Am. Chem. Soc. 1958, 80, 799-800. [CrossRef]

10. Zhang, P.; Gong, Y.; Li, H.; Chen, Z.; Wang, Y. Solvent-free aerobic oxidation of hydrocarbons and alcohols with Pd@N-doped carbon from glucose. Nat. Commun. 2013, 4, 1593. [CrossRef]

11. Chao, S.; Zou, F.; Wan, F.; Dong, X.; Wang, Y.; Wang, Y.; Guan, Q.; Wang, G.; Li, W. Nitrogen-doped carbon derived from ZIF-8 as a high-performance metal-free catalyst for acetylene hydrochlorination. Sci. Rep. 2017, 7, 39789. [CrossRef]

12. Duan, X.; O’Donnell, K.; Sun, H.; Wang, Y.; Wang, S. Sulfur and nitrogen Co-doped graphene for metal-free catalytic oxidation reactions. Small 2015, 11, 3036-3044. [CrossRef] [PubMed]

13. Shi, W.; Zhang, B.; Lin, Y.; Wang, Q.; Zhang, Q.; Su, D.S. Enhanced chemoselective hydrogenation through tuning the interaction between $\mathrm{Pt}$ nanoparticles and carbon supports: Insights from identical location transmission electron microscopy and X-ray photoelectron spectroscopy. ACS Catal. 2016, 7844-7854. [CrossRef]

14. Zhang, X.; Wang, N.; Geng, L.; Fu, J.; Hu, H.; Zhang, D.; Zhu, B.; Carozza, J.; Han, H. Facile synthesis of ultrafine cobalt oxides embedded into $\mathrm{N}$-doped carbon with superior activity in hydrogenation of 4-nitrophenol. J. Colloid Interface Sci. 2018, 512, 844-852. [CrossRef] [PubMed]

15. Zhu, Y.; Yu, G.; Yang, J.; Yuan, M.; Xu, D.; Dong, Z. Biowaste soybean curd residue-derived Pd/nitrogen-doped porous carbon with excellent catalytic performance for phenol hydrogenation. J. Colloid Interface Sci. 2019, 533, 259-267. [CrossRef] [PubMed]

16. Fiorio, J.L.; Gonçalves, R.V.; Teixeira-Neto, E.; López, N.; Rossi, L.M. Accessing frustrated lewis pair chemistry through robust gold@N-doped carbon for selective hydrogenation of alkynes. ACS Catal. 2018, 8, 3516-3524. [CrossRef]

17. Pisduangdaw, S.; Mekasuwandumrong, O.; Fujita, S.I.; Arai, M.; Yoshida, H.; Panpranot, J. One step synthesis of $\mathrm{Pt}-\mathrm{Co} / \mathrm{TiO}_{2}$ catalysts by flame spray pyrolysis for the hydrogenation of 3-nitrostyrene. Catal. Commun. 2015, 61, 11-15. [CrossRef]

18. Chu, K.; Wang, F.; Tian, Y.; Wei, Z. Phosphorus doped and defects engineered graphene for improved electrochemical sensing: Synergistic effect of dopants and defects. Electrochim. Acta 2017, 231, 557-564. [CrossRef]

19. Ayusheev, A.B.; Taran, O.P.; Seryak, I.A.; Podyacheva, O.Y.; Descorme, C.; Besson, M.; Kibis, L.S.; Boronin, A.I.; Romanenko, A.I.; Ismagilov, Z.R.; et al. Ruthenium nanoparticles supported on nitrogen-doped carbon nanofibers for the catalytic wet air oxidation of phenol. Appl. Catal. B Environ. 2014, 146, 177-185. [CrossRef]

20. Zhao, L. Natural phosphorus-doped honeycomb carbon materials as oxygen reduction catalysts derived from pulsatilla chinensis (bunge) regel. RSC Adv. 2017, 7, 13904-13910. [CrossRef] 
21. Lu, C.; Wang, M.; Feng, Z.; Qi, Y.; Feng, F.; Ma, L.; Zhang, Q.; Li, X. A phosphorus-carbon framework over activated carbon supported palladium nanoparticles for the chemoselective hydrogenation of para-chloronitrobenzene. Catal. Sci. Technol. 2017, 7, 1581-1589. [CrossRef]

22. Hita, I.; Cordero-Lanzac, T.; Gallardo, A.; Arandes, J.M.; Rodríguez-Mirasol, J.; Bilbao, J.; Cordero, T.; Castaño, P. Phosphorus-containing activated carbon as acid support in a bifunctional Pt-Pd catalyst for tire oil hydrocracking. Catal. Commun. 2016, 78, 48-51. [CrossRef]

23. Liu, Z.; Shi, Q.; Zhang, R.; Wang, Q.; Kang, G.; Peng, F. Phosphorus-doped carbon nanotubes supported low Pt loading catalyst for the oxygen reduction reaction in acidic fuel cells. J. Power Sources 2014, 268, 171-175. [CrossRef]

24. Wang, B.; Yu, L.; Zhang, J.; Pu, Y.; Zhang, H.; Li, W. Phosphorus-doped carbon supports enhance gold-based catalysts for acetylene hydrochlorination. RSC Adv. 2014, 4, 15877. [CrossRef]

25. Zhuang, M.; Ou, X.; Dou, Y.; Zhang, L.; Zhang, Q.; Wu, R.; Ding, Y.; Shao, M.; Luo, Z. Polymer-embedded fabrication of $\mathrm{Co}_{2} \mathrm{P}$ nanoparticles encapsulated in N,P-doped graphene for hydrogen generation. Nano Lett. 2016, 16, 4691-4698. [CrossRef]

26. Song, P.; Zhu, L.; Bo, X.; Wang, A.; Wang, G.; Guo, L. Pt nanoparticles incorporated into phosphorus-doped ordered mesoporous carbons: Enhanced catalytic activity for methanol electrooxidation. Electrochim. Acta 2014, 127, 307-314. [CrossRef]

27. Xue, X.; Ge, J.; Liu, C.; Xing, W.; Lu, T. Novel chemical synthesis of Pt-Ru-P electrocatalysts by hypophosphite deposition for enhanced methanol oxidation and $\mathrm{CO}$ tolerance in direct methanol fuel cell. Electrochem. Commun. 2006, 8, 1280-1286. [CrossRef]

28. Xue, X.; Ge, J.; Tian, T.; Liu, C.; Xing, W.; Lu, T. Enhancement of the electrooxidation of ethanol on Pt-Sn-P/C catalysts prepared by chemical deposition process. J. Power Sources 2007, 172, 560-569. [CrossRef]

29. Tong, Y.C.; Zhang, X.Y.; Wang, Q.Y.; Xu, X.J. The adsorption mechanism of platinum on phosphorus-doped single walled carbon nanotube. Comput. Theor. Chem. 2015, 1059, 1-6. [CrossRef]

30. Paradies, J. Metal-free hydrogenation of unsaturated hydrocarbons employing molecular hydrogen. Angew. Chem. Int. Ed. 2014, 53, 3552-3557. [CrossRef]

31. Wang, L.; Wang, L.; Zhang, J.; Liu, X.; Wang, H.; Zhang, W.; Yang, Q.; Ma, J.; Dong, X.; Yoo, S.J.; et al. Selective hydrogenation of $\mathrm{CO}_{2}$ to ethanol over cobalt catalysts. Angew. Chem. Int. Ed. 2018, 57, 6104-6108. [CrossRef]

32. Wang, C.; Wang, L.; Zhang, J.; Wang, H.; Lewis, J.P.; Xiao, F. Product selectivity controlled by zeolite crystals in biomass hydrogenation over a palladium catalyst. J. Am. Chem. Soc. 2016, 138, 7880-7883. [CrossRef]

33. Albani, D.; Shahrokhi, M.; Chen, Z.; Mitchell, S.; Hauert, R.; López, N.; Pérez-Ramírez, J. Selective ensembles in supported palladium sulfide nanoparticles for alkyne semi-hydrogenation. Nat. Commun. 2018, 9, 2634. [CrossRef] [PubMed]

34. Durndell, L.J.; Parlett, C.M.A.; Hondow, N.S.; Isaacs, M.A.; Wilson, K.; Lee, A.F. Selectivity control in Pt-catalyzed cinnamaldehyde hydrogenation. Sci. Rep. 2015, 5, 9425. [CrossRef]

35. Hidalgo-Carrillo, J.; Sebti, J.; Marinas, A.; Marinas, J.M.; Sebti, S.; Urbano, F.J. XPS evidence for structure-performance relationship in selective hydrogenation of crotonaldehyde to crotyl alcohol on platinum systems supported on natural phosphates. J. Colloid Interface Sci. 2012, 382, 67-73. [CrossRef] [PubMed]

36. Bornschein, C.; Werkmeister, S.; Wendt, B.; Jiao, H.; Alberico, E.; Baumann, W.; Junge, H.; Junge, K.; Beller, M. Mild and selective hydrogenation of aromatic and aliphatic (di)nitriles with a well-defined iron pincer complex. Nat. Commun. 2014, 5, 4111. [CrossRef]

37. Lu, X.; He, J.; Jing, R.; Tao, P.; Nie, R.; Zhou, D.; Xia, Q. Microwave-activated Ni/carbon catalysts for highly selective hydrogenation of nitrobenzene to cyclohexylamine. Sci. Rep. 2017, 7, 2676. [CrossRef]

38. Chatterjee, M.; Chatterjee, A.; Kawanami, H.; Ishizaka, T.; Suzuki, T.; Suzuki, A. Rapid hydrogenation of aromatic nitro compounds in supercritical carbon dioxide: Mechanistic implications via experimental and theoretical investigations. Adv. Synth. Catal. 2012, 354, 2009-2018. [CrossRef]

39. Wang, K.; Gao, W.; Jiang, P.; Lan, K.; Yang, M.; Huang, X.; Ma, L.; Niu, F.; Li, R. Bi-functional catalyst of porous $\mathrm{N}$-doped carbon with bimetallic $\mathrm{FeCu}$ for solvent-free resultant imines and hydrogenation of nitroarenes. Mole. Catal. 2019, 465, 43-53. [CrossRef]

40. Budi, C.S.; Saikia, D.; Chen, C.-S.; Kao, H.-M. Catalytic evaluation of tunable Ni nanoparticles embedded in organic functionalized $2 \mathrm{D}$ and $3 \mathrm{D}$ ordered mesoporous silicas from the hydrogenation of nitroarenes. $J$. Catal. 2019, 370, 274-288. [CrossRef] 
41. Sreedhar, B.; Devi, D.K.; Yada, D. Selective hydrogenation of nitroarenes using gum acacia supported Pt colloid an effective reusable catalyst in aqueous medium. Catal. Commun. 2011, 12, 1009-1014. [CrossRef]

42. Veerakumar, P.; Thanasekaran, P.; Lin, K.-C.; Liu, S.-B. Well-dispersed rhenium nanoparticles on three-dimensional carbon nanostructures: Efficient catalysts for the reduction of aromatic nitro compounds. J. Colloid Interface Sci. 2017, 506, 271-282. [CrossRef] [PubMed]

43. Wang, X.; He, Y.; Liu, Y.; Park, J.; Liang, X. Atomic layer deposited Pt-Co bimetallic catalysts for selective hydrogenation of $\alpha, \beta$-unsaturated aldehydes to unsaturated alcohols. J. Catal. 2018, 366, 61-69. [CrossRef]

44. Han, X.; Zhou, R.; Yue, B.; Zheng, X. Selective hydrogenation of cinnamaldehyde over Pt/ $/ \mathrm{rO}_{2}$ catalyst modified by Cr, Mn, Fe, Co and Ni. Catal. Lett. 2006, 109, 157-161. [CrossRef]

45. Li, Y.; Zhu, P.-F.; Zhou, R.-X. Selective hydrogenation of cinnamaldehyde to cinnamyl alcohol with carbon nanotubes supported Pt-Co catalysts. Appl. Surf. Sci. 2008, 254, 2609-2614. [CrossRef]

46. Tian, Z.; Li, Q.; Hou, J.; Pei, L.; Li, Y.; Ai, S. Platinum nanocrystals supported on CoAl mixed metal oxide nanosheets derived from layered double hydroxides as catalysts for selective hydrogenation of cinnamaldehyde. J. Catal. 2015, 331, 193-202. [CrossRef]

47. Tian, Z.; Liu, C.; Li, Q.; Hou, J.; Li, Y.; Ai, S. Nitrogen- and oxygen-functionalized carbon nanotubes supported Pt-based catalyst for the selective hydrogenation of cinnamaldehyde. Appl. Catal. A Gen. 2015, 506, 134-142. [CrossRef]

48. Chen, T.; Rodionov, V.O. Controllable catalysis with nanoparticles: Bimetallic alloy systems and surface adsorbates. ACS Catal. 2016, 6, 4025-4033. [CrossRef]

49. Wang, H.; Bai, S.; Pi, Y.; Shao, Q.; Tan, Y.; Huang, X. A strongly coupled ultrasmall $\mathrm{Pt}_{3}$ Co nanoparticle-ultrathin $\mathrm{Co}(\mathrm{OH})_{2}$ nanosheet architecture enhances selective hydrogenation of $\alpha, \beta$-unsaturated aldehydes. ACS Catal. 2019, 9, 154-159. [CrossRef]

50. Wu, Q.; Zhang, B.; Zhang, C.; Meng, X.; Su, X.; Jiang, S.; Shi, R.; Li, Y.; Lin, W.; Arai, M.; et al. Significance of surface oxygen-containing groups and heteroatom $\mathrm{P}$ species in switching the selectivity of $\mathrm{Pt} / \mathrm{C}$ catalyst in hydrogenation of 3-nitrostyrene. J. Catal. 2018, 364, 297-307. [CrossRef]

51. Lu, X.H.; Shen, Y.; He, J.; Jing, R.; Tao, P.P.; Hu, A.; Nie, R.F.; Zhou, D.; Xia, Q.H. Selective hydrogenation of benzoic acid to cyclohexane carboxylic acid over microwave-activated Ni/carbon catalysts. Mol. Catal. 2018, 444, 53-61. [CrossRef]

52. Musci, J.J.; Merlo, A.B.; Casella, M.L. Aqueous phase hydrogenation of furfural using carbon-supported Ru and RuSn catalysts. Catal. Today 2017, 296, 43-50. [CrossRef]

53. Chang, J.; Xiao, Y.; Xiao, M.; Ge, J.; Liu, C.; Xing, W. Surface oxidized cobalt-phosphide nanorods as an advanced oxygen evolution catalyst in alkaline solution. ACS Catal. 2015, 5, 6874-6878. [CrossRef]

54. Prins, R.; Bussell, M.E. Metal phosphides: Preparation, characterization and catalytic reactivity. Catal. Lett. 2012, 142, 1413-1436. [CrossRef]

55. Infantes-Molina, A.; Cecilia, J.A.; Pawelec, B.; Fierro, J.L.G.; Rodríguez-Castellón, E.; Jiménez-López, A. Ni 2 P and CoP catalysts prepared from phosphite-type precursors for HDS-HDN competitive reactions. Appl. Catal. A Gen. 2010, 390, 253-263. [CrossRef]

56. Sennu, P.; Kim, H.S.; An, J.Y.; Aravindan, V.; Lee, Y.S. Synthesis of 2D/2D structured mesoporous $\mathrm{Co}_{3} \mathrm{O}_{4}$ nanosheet/N-doped reduced graphene oxide composites as a highly stable negative electrode for lithium battery applications. Chem. Asian J. 2015, 10, 1776-1783. [CrossRef]

57. Hasegawa, G.; Deguchi, T.; Kanamori, K.; Kobayashi, Y.; Kageyama, H.; Abe, T.; Nakanishi, K. High-level doping of nitrogen, phosphorus, and sulfur into activated carbon monoliths and their electrochemical capacitances. Chem. Mater. 2015, 27, 4703-4712. [CrossRef]

58. Patel, M.A.; Luo, F.; Khoshi, M.R.; Rabie, E.; Zhang, Q.; Flach, C.R.; Mendelsohn, R.; Garfunkel, E.; Szostak, M.; He, H. P-doped porous carbon as metal free catalysts for selective aerobic oxidation with an unexpected mechanism. ACS Nano 2016, 10, 2305-2315. [CrossRef]

59. Shimizu, K.-i.; Miyamoto, Y.; Kawasaki, T.; Tanji, T.; Tai, Y.; Satsuma, A. Chemoselective hydrogenation of nitroaromatics by supported gold catalysts: Mechanistic reasons of size- and support-dependent activity and selectivity. J. Phys. Chem. C 2009, 113, 17803-17810. [CrossRef]

60. Tan, Y.; Liu, X.Y.; Zhang, L.; Wang, A.; Li, L.; Pan, X.; Miao, S.; Haruta, M.; Wei, H.; Wang, H.; et al. $\mathrm{ZnAl}$-hydrotalcite-supported $\mathrm{Au}_{25}$ nanoclusters as precatalysts for chemoselective hydrogenation of 3-nitrostyrene. Angew. Chem. Int. Ed. 2017, 56, 2709-2713. [CrossRef] 
61. Shimizu, K.-i.; Miyamoto, Y.; Satsuma, A. Size- and support-dependent silver cluster catalysis for chemoselective hydrogenation of nitroaromatics. J. Catal. 2010, 270, 86-94. [CrossRef]

62. Yoshida, H.; Kato, K.; Wang, J.; Meng, X.; Narisawa, S.; Fujita, S.I.; Wu, Z.; Zhao, F.; Arai, M. Hydrogenation of nitrostyrene with a $\mathrm{Pt} / \mathrm{TiO}_{2}$ catalyst in $\mathrm{CO}_{2}$-dissolved expanded polar and nonpolar organic liquids: Their macroscopic and microscopic features. J. Phys. Chem. C 2011, 115, 2257-2267. [CrossRef]

63. Minejima, C.; Ebata, T.; Mikami, N. C-H stretching vibrations of benzene and toluene in their S1 states observed by double resonance vibrational spectroscopy in supersonic jets. PCCP 2002, 4, 1537-1541. [CrossRef]

64. Supriya, P.; Srinivas, B.T.V.; Chowdeswari, K.; Naidu, N.V.S.; Sreedhar, B. Biomimetic synthesis of gum acacia mediated $\mathrm{Pd}-\mathrm{ZnO}$ and $\mathrm{Pd}-\mathrm{TiO}_{2}$-promising nanocatalysts for selective hydrogenation of nitroarenes. Mater. Chem. Phys. 2018, 204, 27-36. [CrossRef]

65. Nan, J.; Yu, H.B.; Xue, Q.S.; Li, Y.D. In situ FT-IR study on hydrogenation of olefin and aromatic on Pd-based metal catalysts. Chem. Eng. Oil Gas 2009, 38, 183-188.

(C) 2019 by the authors. Licensee MDPI, Basel, Switzerland. This article is an open access article distributed under the terms and conditions of the Creative Commons Attribution (CC BY) license (http://creativecommons.org/licenses/by/4.0/). 